向 野 義 人* 荒川 規矩男

要旨 肥満の耳針療法における右刺激と左刺激の効果差と味覚変化効 果を検討した。方法(1)では39例の単純性肥満を無作為に両側肺点治療 群(BL), 右噴門肺点治療群 $\left(\mathrm{R}_{1}\right)$ に分けた。方法(2)では24例の単純性肥 満を無作為に右噴門肺点治療群 $\left(\mathrm{R}_{2}\right)$ と左噴門肺点治療群 $(\mathrm{L})$ とに分け た。各々皮内針で 4 週間治療し, 食欲抑制効果及び体重と味覚の変化 を比較した。その結果(1)でBLの方が食欲抑制効果及び体重減少量が 大で, 塩味覚は $\mathrm{BL}, \mathrm{R}_{1}$ とも過敏となった。(2)で, $\mathrm{R}_{2}$ の治療前塩味覚 閾值は体重減少量に正相関 $(r=0.794)$ L, Lでも同様傾向を示し $(r=$ 0.536), 塩味覚が鈍い程体重減少量が多かったこの回帰直線の傾き は $\mathrm{R}_{2}$ でより急峻 $(\mathrm{p}<0.05)$ であり，右刺激が左刺激より有効であった。

\section{I 緒}

味覚は飲食物を判別しその選択を決める要因と なることから, 肥満に对する耳針療法の作用機序 に味覚変化を介する食物摂取量の減少や食物嗼好 の変化が関与する可能性がある。しかし, 耳針療 法の際の味覚の変化や, 耳針の効果と味覚の関係 についてはまだ知られていない。

一方，耳針の効果はツボの部位により異なる。 例之ば，耳介の迷走神経分布領域や皮電点におい いてより有効 ${ }^{1.2}$ で, 部位の異なる皮電点では効果 の種類に差を認める 激と左側刺激の効果差についてはまだ検討されて いない。

そこで, 我々は耳針療法の際の味覚の変化及び 右側刺激と左側刺激の効果差を同時に検討した。

方 法

1. 对象 年路 20 歳 $\sim 60$ 歳の外来患者で肥満度 110

* Yoshito MUKAINO 福岡大学区学部第二内科

共同研究者: Kikuo ARAKAWA 福岡大学医学部第二内科

Key Words : 単純肥満, 耳針, 味覚, ろ紙ディスク法, 左 右刺激 $\%\left(\right.$ 肥満度の算定は平田法 ${ }^{4}$ による)以上の者とした。 肥満の合併症のため薬物を内服している者, 空腹 時血糖が $110 \mathrm{mg} / \mathrm{dl}$ を越える者及び症候性肥満を 除外した。

\section{2. 試験方法}

(1)昭和57年 7 月より昭和58年 3 月までの 9 力月 間に受診した対象患者を両側肺点に耳針を行う群 と右側噴門肺点に耳針を行う群とに無作為に分け た。各症例の該当する点を石川式皮電計 PD-1 を 用いて決めた後, 各点に 2 本ずつの皮内針を約 1 $\mathrm{mm}$ の深さに刺入し, 絆創高で固定し留置した。 その後 1 週每に針を交換し， 4 週間治療した。食 欲の変化をみるために掑食量, 空腹感, 満腹感を 6〜 7段階に分類した調查表(表 1 )を毎日記入さ せた。また体重を毎週測定し, 味覚検査を治療前, 治療後 1 週, 4 週に施行した。

(2)昭和58年 4 月から10月までの 7 力月間に受診 した对象患者を右噴門肺点治療群あるいは左噴門 肺点治療群に無作為に分け, 方法(1に準じて検討 した。

\section{3 . 効果判定}

耳針用調查表の一部を表 1 に示した。主食の捸 取量を段階評価し, 各項目に点数を与え, それを 


\section{表 1 耳針用調査カード}

氏名 年齢藏男 $\cdot$ 女

耳針療法開始 年 月 日 開始後 $\quad$ )週目

耳針療法を開始してから治療前と比較して以下の事項はどのように変化しましたか？

あてはまる項目に○印を記入して下さい。

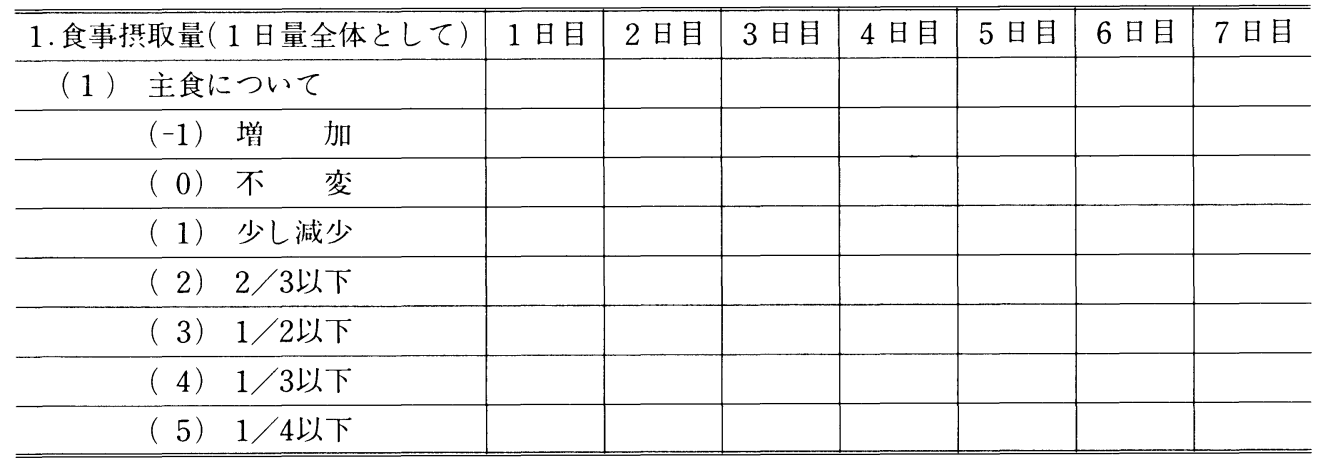

※ (2)副食, (3)間食, 2 . 空腹感, 3. 満腹感についても同様な段階評価で治療による変化を検討し た。

左端に示した。治療前と比較して変化がない場合 を 0 とし，摂取量が減る程得点が多くなるように した。同様な評価法で副食, 間食, 空腹感, 満腹 感を調べた。この調查表を 4 週間毎日記入しても らい, 各要因の 1 日あたりの平均点を症例毎に算 定し，この合計得点をその症例の食欲抑制係数と した。そして食欲抑制係数と体重減少量との関係 を検討した。
味覚検查法を図 1 に示した。この方法は冨田ら により開発された味覚の定性定量検査法で, 容易 に施行でき，再現性が優れている ${ }^{5)}$ 。測定部位と して舌尖より $2 \mathrm{~cm}$ 離れた両側鼓索神経領域を選び, 4 つの基本味質のうち甘味と塩味について調べた。 5 段階の濃度系に分けた各試液を直径 $5 \mathrm{~mm}$ の円 形濾紙 discに滴下し，耳科用ピンセットでこれを 当該部位に置き，味質を判定させた。各味質を低

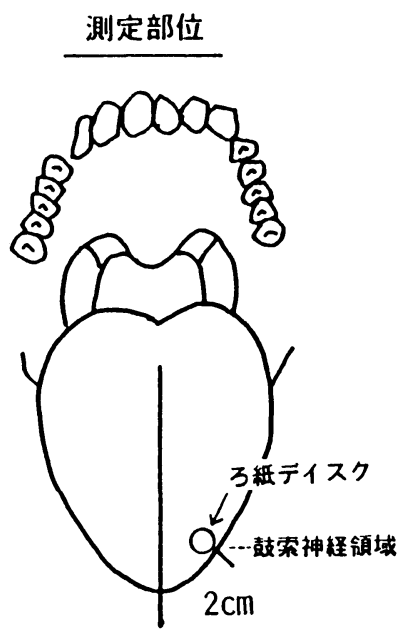

\begin{tabular}{|c|c|c|}
\hline 種類 & 精笠白措 & 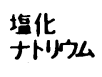 \\
\hline 1 & $0.3 \%$ & $0.3 \%$ \\
\hline 2 & 2.5 & 1.25 \\
\hline 3 & 10 & 5 \\
\hline 4 & 20 & 10 \\
\hline 5 & 80 & 20 \\
\hline 味垢 & 甘味 & 墥味 \\
\hline
\end{tabular}

判定方法

図1味覚の定性定量検査法(冨田法) 


\begin{tabular}{|c|c|c|c|c|c|c|c|c|}
\hline \multirow[t]{4}{*}{ （富田法 } & & & 1 & 2 & 3 & 4 & 5 & \\
\hline & & Sucrose & $0.3 \%$ & 2.5 & 10 & 20 & 80 & \\
\hline & & $\mathrm{NaCl}$ & $0.3 \%$ & 1.25 & 5 & 10 & 20 & \\
\hline & \multicolumn{8}{|c|}{$\downarrow$} \\
\hline & 1 & 2 & 3 & 4 & 5 & 6 & 7 & 8 \\
\hline Sucrose & $0.16 \%$ & 0.31 & 0.63 & 1.25 & 2.5 & 5 & 10 & 20 \\
\hline $\mathrm{NaCl}$ & $0.16 \%$ & 0.31 & 0.63 & 1.25 & 2.5 & 5 & 10 & 20 \\
\hline
\end{tabular}

図2 テイストディスク変法と再現性

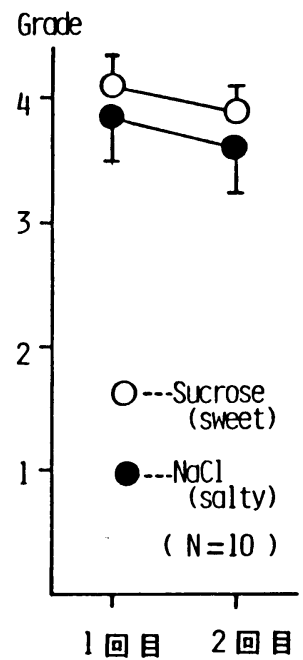

濃度より始め, 味質を認知し得た濃度をもって味 覚閾値とした。富田の判定基準に従い, 味覚閾値 1 を味覚過敏, 2, 3 を味覚正常, 4, 5 を味覚 異常とした。方法(2)では甘味, 塩味の試液濃度系 列をさらに細かくし, 倍数稀釈(図 2 ) として, 味 覚閾值を調べた。 1 週間の間隔をおいて検討した 再現性は良好であった。

なお，測定は方法(1)(2)とも左側を先にし，初回 甘味, 塩味の順でその後の順序を原則として逆に した。

4. 統計処理：治療期間が 3 週間に満たない場合 を脱落とした。データーに応じて, $\mathrm{x}^{2}$ 検定, $\mathrm{t}$ 検 定，分散分析を施行した。

結 果

方法(1)の対象となった症例は39例で両群の年令, 身長, 体重, 肥満度, 味覚閾値の比較を表 2 に示

\section{表2 両群における治療前の}

各パラメーターの平均値と標準誤差

\begin{tabular}{|c|c|c|}
\hline & 右噴門, 肺点群 & 両側肺点群 \\
\hline 症例数 & 20(女19，男 1 ) & 19(女18，男 1 ) \\
\hline 年＼cjkstart令(歳) & $41.2 \pm 1.9$ & $42.4 \pm 2.2$ \\
\hline 身 長 $(\mathrm{cm})$ & $153.5 \pm 1.1$ & $156.3 \pm 1.2$ \\
\hline 体 重( kg) & $63.6 \pm 1.6$ & $66.1 \pm 1.7$ \\
\hline 肥満度 $(\%)$ & $123.8 \pm 3.2$ & $125.6 \pm 2.6$ \\
\hline 味 覚 甘味(右) & $2.3 \pm 0.2$ & $2.3 \pm 0.2$ \\
\hline (Grade) 甘味(左) & $2.5 \pm 0.2$ & $2.2 \pm 0.2$ \\
\hline 塩味 $($ 右) & $2.1 \pm 0.1$ & $2.2 \pm 0.2$ \\
\hline 塩味(左) & $2.2 \pm 0.2$ & $2.1 \pm 0.2$ \\
\hline
\end{tabular}

した。これらのパラメーターにはほとんど差がな かった。また両群とも脱落例はなかった。耳針用 調查表(表 1 )より算定された食欲抑制係数と 4 週 間の体重減少量との関係を図 3 に示した。 $2 \mathrm{~kg}$ 以 上の減量で食欲抑制係数が 6 以上の症例を著効 $(\mathrm{a})$, 減量が $2 \mathrm{~kg}$ 未満でかつ食欲抑制係数が 6 以下の症 例を無効(b), これらの条件以外の症例(b)を有効と すると, 右噴門肺点群では著効 5 例，有効 10 例， 無効 5 例で, 両側肺点群では著効 9 例, 有効 5 例, 無効 5 例であった。有効例及び著効例の合計はほ ぼ同数であったが，著効率は両側肺点群で $47.4 \%$ (9/19), 右噴門肺点群で $25 \%(5 / 20)$, 平均体重減 少量はそれぞれ1. $7 \pm 0.2 \mathrm{~kg}, 1.5 \pm 0.3 \mathrm{~kg}$ と両側肺 点治療群の方が有用であると考えられた。しかし

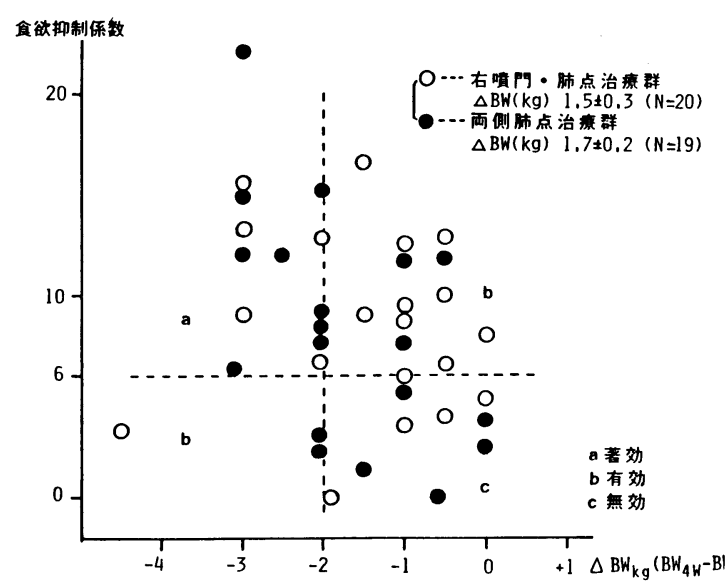

図3両群における食欲抑制係数と体重減少量 


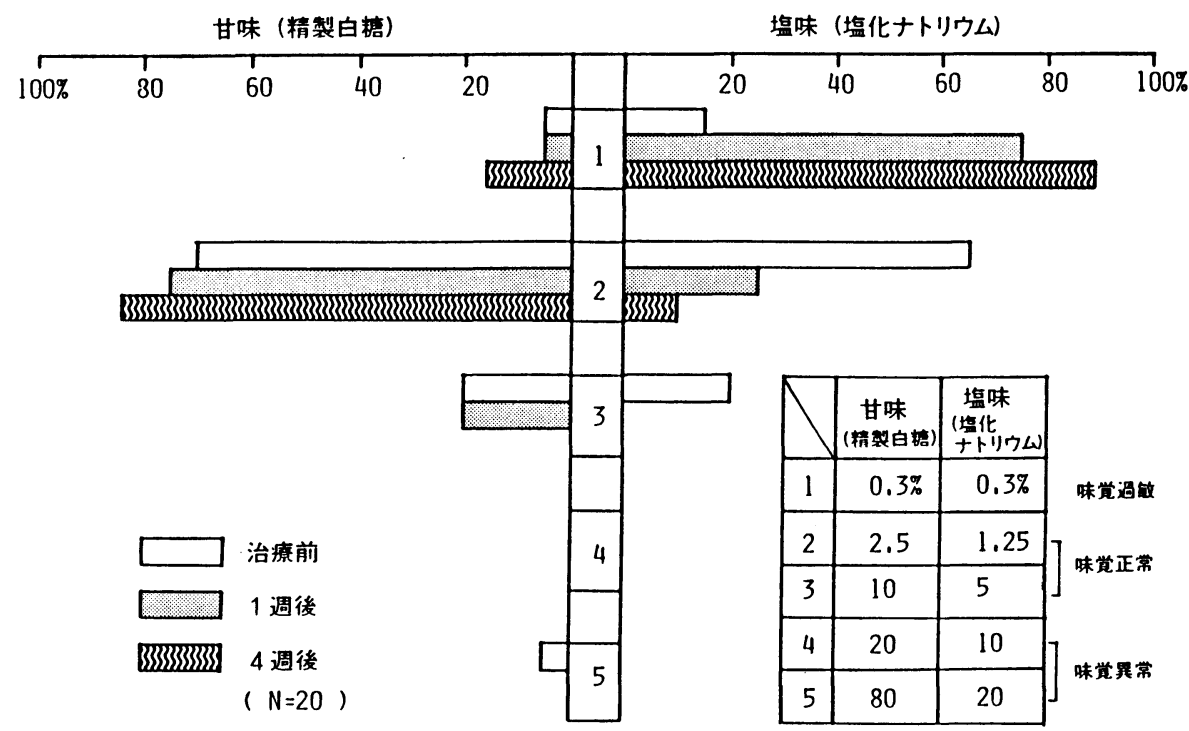

図4 右噴門・肺点治療群における味覚の変化(右鼓索神経領域)

有意な群間差は認めなかった。

治療前, 治療後 1 週, 4 週の甘味, 塩味の味覚 閾値の度数分布を比較した(図 4 )。

治療前の甘味，塩味の味覚閾値では正常域であ る $2 ， 3$ を占める割合が症例の $80 \%$ を越えていた。 1 週後甘味覚の変化はほとんどないが，塩味覚は 過敏域である 1 の症例が約 $80 \%$ 占め, さらに 4 週後にはこの傾向は著明となった。一方，甘味覚 は 4 週後にはやや改善傾向を認めた。このような 味覚の変化は両側肺点治療群でも同様に認められ, しかも舌の左右においてもほとんど差がなかった。

方法(2)の対象となった症例は24例(表 3 )で, 両 群の身長, 体重, 肥満度, 味覚閾値はほとんど差

表3 両群における治療前の

\section{各パラメーターの平均値と標準誤差}

\begin{tabular}{|c|c|c|}
\hline & 右噴門, 肺点群 & 左噴門, 肺点群 \\
\hline 症例数 & 13(女11, 男 2 ) & 11 (女11, 男 0 ) \\
\hline 年＼cjkstart令(歳) & $38.2 \pm 1.3$ & $42.6 \pm 2.3$ \\
\hline 身 長 $(\mathrm{cm})$ & $155.0 \pm 1.3$ & $155.1 \pm 1.1$ \\
\hline 体 重( $(\mathrm{kg})$ & $66.0 \pm 1.5$ & $66.6 \pm 2.3$ \\
\hline 肥満度(\%) & $127.1 \pm 2.1$ & $128.0 \pm 3.7$ \\
\hline 味 覚 甘味(右) & $4.3 \pm 0.5$ & $4.0 \pm 0.5$ \\
\hline (Grade) 甘味(左) & $4.3 \pm 0.5$ & $4.2 \pm 0.6$ \\
\hline 塩味(右) & $3.5 \pm 0.4$ & $3.4 \pm 0.4$ \\
\hline 塩味(左) & $3.4 \pm 0.3$ & $3.5 \pm 0.5$ \\
\hline
\end{tabular}

がなかった。年令において右噴門肺点部の方がや や若い傾向にあるが有意差はなかった。治療開始 前の塩味覚閾值と 4 週間の体重減少量の相関を両 群で比較したものを図 5 に示した。右噴門肺点群 では塩味覚閾值と体重減少量の間には有意な正相 関 $(r=0.794, p<0.01)$ があった。また左噴門肺点 群でも同様の傾向を認めたが, 統計学的には有意 でなかった。両群の分散に差がないにもかかわら ず，右噴門肺点群と左噴門肺点群の回帰直線の傾 きには有意の差を認めた。一方，甘味覚閾值と体

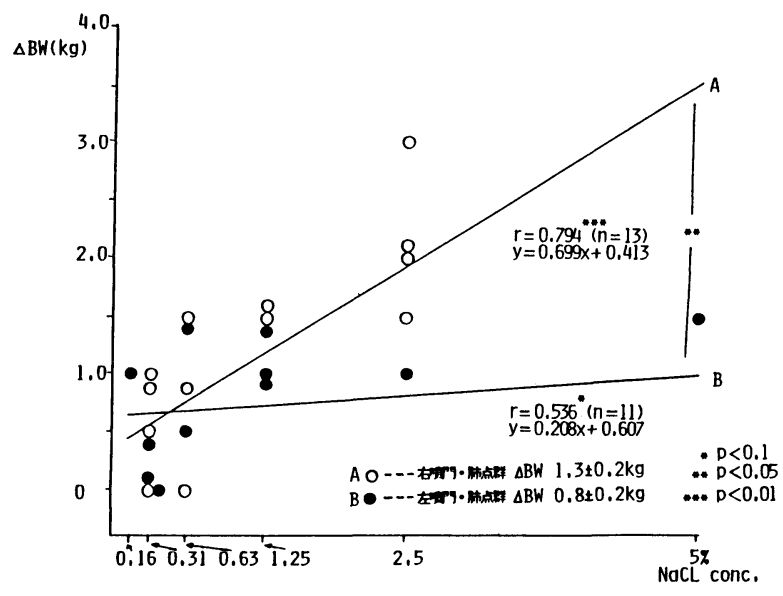

図5両群における治療前塩味覚閾値と 体重減少量の相関 
重減少量の間に相関関係はなかった。また 4 週間 の平均体重減少量は右噴門肺点群 $1.3 \mathrm{~kg}$ に対して 左噴門肺点群は $0.8 \mathrm{~kg}$ であった。

\section{II 考察}

今回の検討で肥満の耳針療法の際には特に塩味 が過敏となることが明らかとなった。対照群をお いた急性実験でも塩味覚は顕著に過敏となる（未 発表)ことから，この味覚閾值の変化は耳針の効果 によるものであると考えられる。

耳針療法の際には，料理が非常にうす味になっ たと家族や知人に指摘されたとか外食が塩辛くて 食べられないなどの訴えをする人が非常に多い。 これらのことは塩味覚過敏が食塩摂取量の減少を もたらしていることを示唆している。

一方，塩味覚が鈍い程食塩摂取量が多いと考之 られ，体内における水分貯留がより多くなってい ることが推測される。塩味覚が鈍い程耳針による 体重減少量が多かった事は，少なくとも耳針療法 には体内に貯留した過利な水分を排泄させる効果 があることを示唆するとともに，同一刺激であっ ても刺激を受ける側の条件で耳針の効果に差が出 ることつまり，耳針療法がいわゆる固太りより水 肥りに有効であることも示唆している。

耳介刺激による味覚閾值の変化の機序は未だ明 らかでないが，興味あることは耳介に分布する脳 神経と味覚を伝達する脳神経が一致していること である。つまり味覚を伝達する神経は舌咽神経, 迷走神経，顔面神経の分枝である鼓索神経及び大 錐体神経であることが知られており ${ }^{6}$ ，耳介にもこ の3 神経の分布があると考之られている。また味 覚の伝導路の分枝が視床下部の外側視床下野（摂 食中枢)に至り，摂食中枢と満腹中枢の相互連絡か あること ${ }^{8}$ 満腹中枢や拱食中枢による掑食行動の制 御に味覚の変化を介する機序が存在すること ${ }^{8)}$ 及び 視床下部性肥満ラットに及ぼす耳針の効果が肥満 中枢を介して発現されると考えられること ${ }^{91}$ は耳針 による求心収刺激が味覚の伝導路と何らかの関係 があることを推定させる。

耳針により塩味覚が過敏となることは，食塩捸 取量がその病態に大きく関わってくる高血圧症を はじめとする諸疾患にも耳針を広し応用できる可
能性があると考えられる。

また，耳針の効果が脳神経分布や皮膚電気抵抗

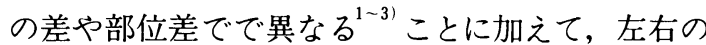
刺激差で異なり，右刺激が有効であったことは耳 針の効果が脳の優位半球とも関わりを持つ可能性 を示唆しており，今後検討すべき課題の一つと考 えられる。

\section{III 結果}

耳針により塩味覚が過敏となった。治療前の塩 味覚が鈍い程，体重減少量が多かった。両側肺点 治療群，右噴門肺点治療群，左噴門肺点治療群の 順に効果があると考えられた。特に右刺激と左刺 激の間には有意の差があり，右刺激がより有効で あった。

\section{参考文献}

1）向野義人：肥満の耳針療法（有効性及びその作 用機序についての検討), 全日本鍼炎学会雑誌 31(1);67. (1981)

2）向野義人, 恒矢保雄, 服部徽：肥満の耳針療法 （皮電点の意義について），全日本銊炎学会雑誌 32(3);226. (1983)

3）向野義人, 恒矢保雄, 荒川規矩男：肥満の耳針 療法における噴門点と肺点の効果差，全日本鋮 炎学会誌 33(3)；279.（1984）

4）阿部正和：成人の肥満一成因，判定一臨床のあ ゆみ 2(3); 18。(1982)

5）富田寛：現代臨床機能検查一味覚検查, 日本臨 床 37(夏季增刊)1897(1979)

6）佐藤昌康：味覚の受容器と伝導経路，新生理学 上巻, 問田直幹他編, 5 版, 医学書院, 東京 (1982)p.790

7）M.H.CHO：欧米耳針法の理論と臨床，医道の 日本, 東京 (1979)p.70

8）大村裕：中枢性食欲の調節に関する最新の知見, 最新医学 38(2);217. (1983)

9) Mukaino. Y, Arakawa, $\mathrm{K}$ and Tsuneya $\mathrm{Y}$ : The effects of ear acupuncture on rats with hypolhalamic obesity. Abstract. World Congress on Scientific Awpuncture P.85 (Vienna. Austria. 1983)

（テ814-01 福岡市城南区七隈7-45-1 福岡大学医学部第二内科) 


\title{
Change of Taste by Ear Acupuncture in Simple Obese Patients
}

\author{
Yoshito Mukaino, Kikuo Arakawa \\ 2nd Department of Internal Medicine, Fukuoka University School of Medicine.
}

Differences between right-side and left-side stimulations in ear acupuncture treatment for obesity were examined. In Method I, 39 patients with simple obesity were randomly divided into two groups: bilateral lung points stimulation group $(B L)$ and right cardia point stimulation group $\left(\mathrm{R}_{1}\right)$. In Method II, 24 patients with simple obesity were randomly divided into two groups: right cardia points st mulation group $\left(\mathrm{R}_{2}\right)$ and that of left one $(\mathrm{L})$. Ear acupuncture. was undertaken for both groups for four weeks. The appetite depressing effect and change of body weight and taste were compared. In Method I, BL showed better appetite-depressing effect and body weight loss than $\mathrm{R}_{1}$. Highly increased salt-taste sensitivity was seen in both $B L$ and $R_{1}$ groups. Positive correlation was seen between pretreatment salt-taste threshold and amount of body weight loss in $\left(\mathrm{R}_{2}\right)$ group $(\mathrm{r}=0.794)$, and the same tendency was also seen in $\mathrm{L}(\mathrm{r}=0.536)$, i. e. the higher pretreatment threshold, the larger amount of wight loss. The fact that more abrupt tilt of regression line was seen in $\left(\mathrm{R}_{2}\right)$ suggests that stimulation of the right-side pointI was more effective than that of leftside. 